\title{
MERCURY POLLUTION FROM SMALL GOLD MINES IN CHINA
}

\author{
YUHUAN LIN, MINGXIN GUO and WEIMING GAN* \\ Research Center for Eco-Environmental Sciences, Academia, Sinica \\ P.O. Box 2871, Haidian, Beijing 100085, China \\ * Jiangxi Institute of Occupational Disease Prevention, Nanchang 330002, China
}

Abstract. Small scale gold mining activity in some mountainous areas of China has caused a series of $\mathrm{Hg}$ pollution problems. Preliminary study indicated that impacts of $\mathrm{Hg}$ pollution on the surrounding environment, air, water and soil are dramatic, and human contamination requires attention.

\section{Introduction}

Gold mining activity in a developing country such as China plays an important role in economic progress. The production of gold in China increases annually at almost $10 \%$ in recent years. In 1995 China produced 105 tons of gold, about one-third of which was from small-scale mines. Those small scale gold mines were located in China's mountainous areas, and their distribution is shown in Figure 1.

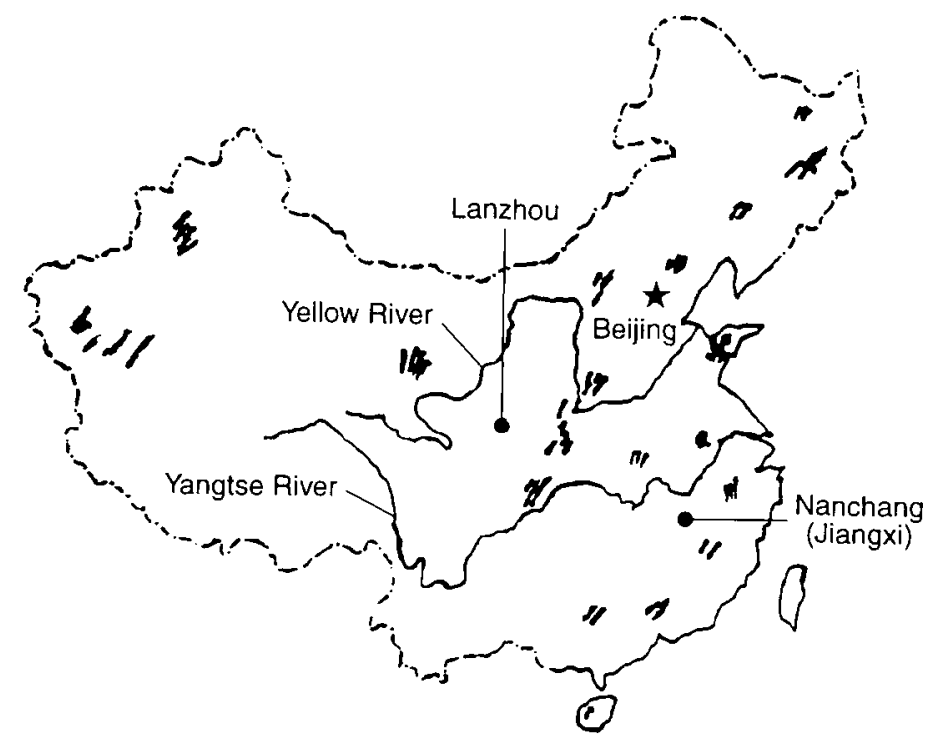

Figure 1. The distribution of small scale gold mines in China

The distribution of gold mines from the north to the south part of China demonstrates the regional difference in mineral types. These are: alluvial ore, rock ore, and co-existing ore. The alluvial gold mineral is mainly exploited by individuals, and about half of rock gold mineral and co-existing gold mineral were mined by individuals and collective units (comparing with those by national units). Where individuals and collective units were 
short of funds, equipment and techniques, they usually exploited small gold mines with simple tools and extracted gold with $\mathrm{Hg}$ amalgamation. Typically, there are two types of gold extraction processes of $\mathrm{Hg}$ amalgamation as shown in Figure 2.

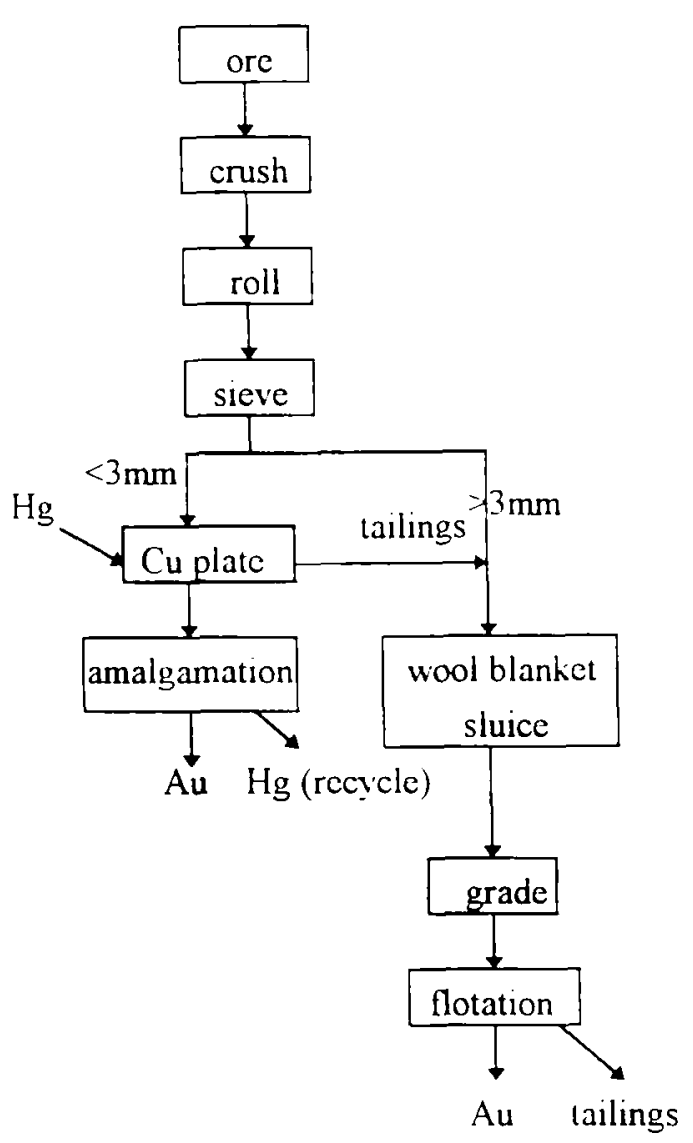

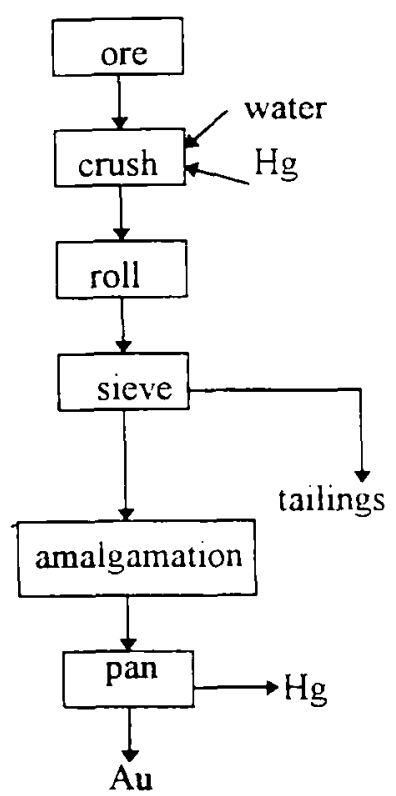

b. Hg amalgamation, 10T/d

\section{a. Hg amalgamation plus flotation, 50T/d}

\section{Figure 2. Process of small scale gold mining}

Hg pollution from small gold mining activities seemed to be serious in China but little data existed. The investigation on the use of $\mathrm{Hg}$ in gold mining and its environmental problems in China was initiated by SCOPE CHINA/CAST in 19931994. Small scale gold mining in many mountainous areas, such as Jilin, Hebei, Henan, Shandong, Shanxi, Hunan, Jiangxi, Sichuan, Hainan Province was popular in earlier 90s', and caused $\mathrm{Hg}$ pollution. The concentration of $\mathrm{Hg}$ in field air, water, tailings, and human bodies exceeded tens times background. Dexing County, Jiangxi Province was taken as one site to show such problem. 


\section{Case study}

Dexing County of Jiangxi Province is one of the sites located in south China which is abundant in non-ferrous mineral resources mixed with $\mathrm{Au}$ ores. It had around 200 small scale gold mines using $\mathrm{Hg}$ amalgamation to extract gold in 1990-1995 as shown in Figure 3. As there were no special workplaces, individuals and collective units usually extracted gold in their living houses, and caused $\mathrm{Hg}$ pollution to the surrounding environment of the villages and impacts on the villagers.

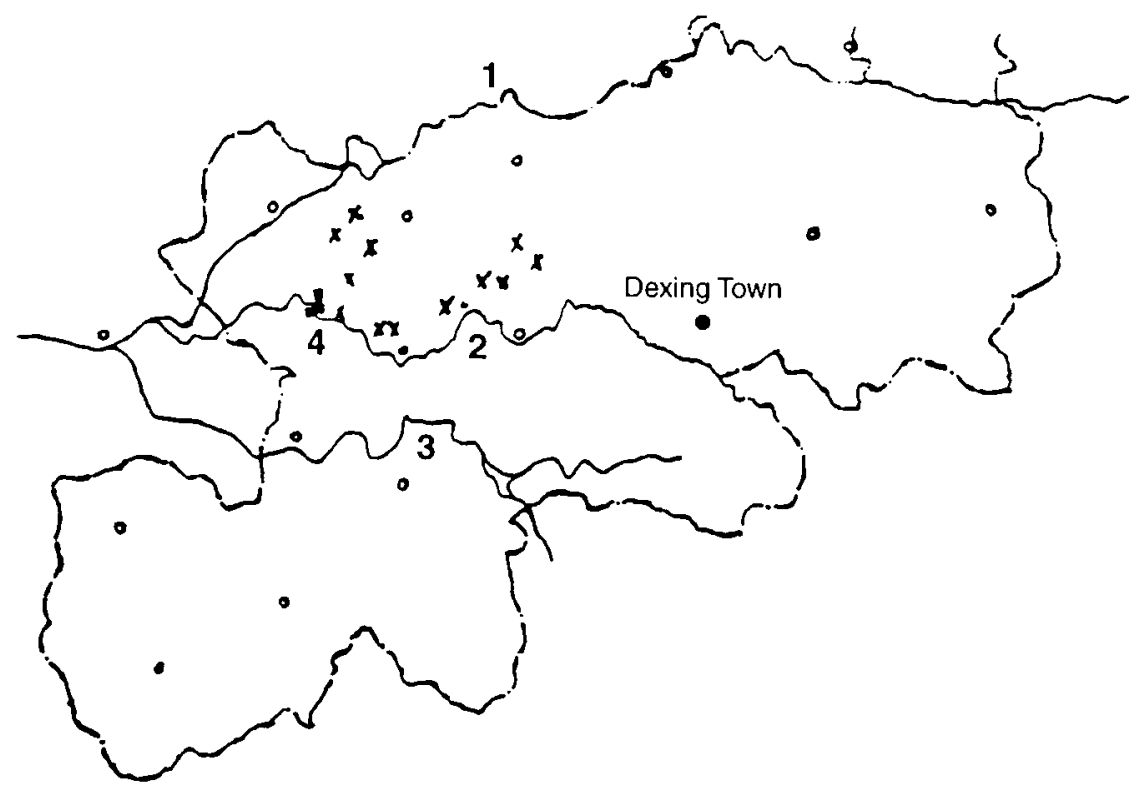

Figure 3. Small scale gold mining in Dexing County, Jiangxi Province, China

A general survey was undertaken in two villages named Shangluo and Zhangjiaban in Dexing County. Samples were taken from 4 families near Jishui River (Figure 4). The villagers transported gold ore from mines to their houses, then used their houses as workrooms to extract gold. The layout of the typical houses in one of the families was shown in Figure 5.

Air samples were collected by GS-« 2 » Type Sampler with gold wire, $1.5 \mathrm{~m}$ above the ground at $0.5 \mathrm{~L} / \mathrm{min}, 60$ minutes for each sample (NEPA, 1989). $\mathrm{Hg}$ was determined by YYG-3 cold atomic fluorometer using Argon as carrier for $\mathrm{Hg}$ vapor. Four samples were collected per day for each location. River water, well water, waste water and tailings (discharged) samples were collected with plastic bottles soaked by diluted $\mathrm{HNO}_{3}$, digested by $\mathrm{HNO}_{3} \mathrm{H}_{2} \mathrm{SO}_{4} \mathrm{KMnO}_{4}$, and tested the content of $\mathrm{Hg}$ content by YYG-3 cold atomic fluorometer. 


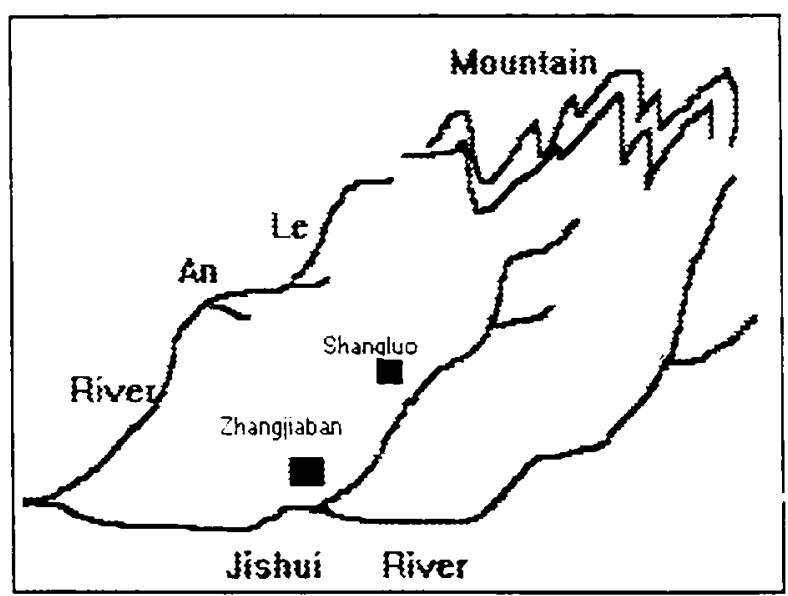

Figure 4. The Location of the Villages in Dexing County

To investigate the impacts of $\mathrm{Hg}$ pollution on human health, urine samples were taken from 185 villagers who contacted $\mathrm{Hg}$ directly. 131 adult men, 21 adult women, 33 children under 16 years old were included. $\mathrm{Hg}$ content in urine was analyzed.

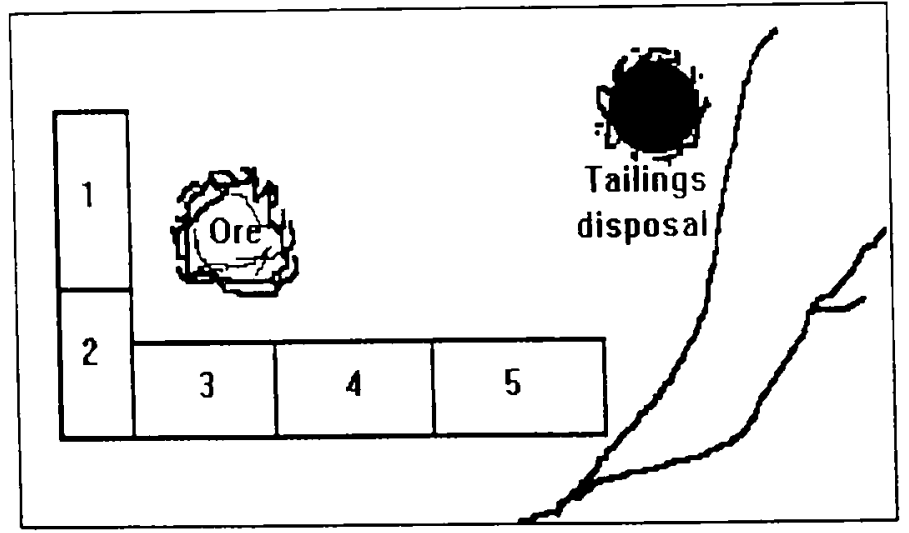

1---Workroom 2---Copper Plate Workshop 3---Bedroom 4---Sitting room 5---Kitchen

Figure 5. The scheme of workplace near riverbank 


\section{Results and discussion}

\subsection{CONCENTRATION OF Hg IN AIR}

Table 1 shows the concentration of $\mathrm{Hg}$ in air from workroom, kitchen, bedroom, sitting room, copper plate workshop. The background value of atmospheric $\mathrm{Hg}$ is $10-20 \mathrm{ng} . \mathrm{m}^{-3}$. According to China's national standards, the content of $\mathrm{Hg}$ in air from living areas is less than $0.0003 \mathrm{mg} \cdot \mathrm{m}^{-3}$, the upper limit of $\mathrm{Hg}$ concentration in air from workplace is 0.01 $\mathrm{mg} . \mathrm{m}^{-3}$. The average content of $\mathrm{Hg}$ in air from these small scale gold mines' workplace exceeded the upper limit by $80-300$ fold. Even in the kitchen, bedroom, sitting room, the content of $\mathrm{Hg}$ in the air also exceeded the permissible value by 8-30 times.

\section{TABLE 1}

Concentration of $\mathrm{Hg}$ in air from different workplaces

\begin{tabular}{lccccc}
\hline $\begin{array}{l}\text { Sample } \\
\text { site }\end{array}$ & $\begin{array}{l}\text { Workroom } \\
\left(\mathrm{mg} \cdot \mathrm{m}^{-3}\right)\end{array}$ & $\begin{array}{l}\text { Kitchen } \\
\left(\mathrm{mg} \cdot \mathrm{m}^{-3}\right)\end{array}$ & $\begin{array}{c}\text { Bedroom } \\
\left(\mathrm{mg} \cdot \mathrm{m}^{-3}\right)\end{array}$ & $\begin{array}{l}\text { Sitting room } \\
\left(\mathrm{mg} \cdot \mathrm{m}^{-3}\right)\end{array}$ & $\begin{array}{l}\text { Copper plate workshop } \\
\left(\mathrm{mg} \cdot \mathrm{m}^{-3}\right)\end{array}$ \\
\hline Wang's House & 2.8432 & 0.0024 & 0.0068 & 0.0038 & 0.9481 \\
Su'House & 1.9456 & 0.0026 & 0.0089 & 0.0044 & 0.7982 \\
Zhang'House & 3.0465 & 0.0054 & 0.0141 & 0.0089 & 1.2577 \\
Li'House & 2.5341 & 0.0048 & 0.0099 & 0.0045 & 0.9960 \\
\hline Average & 2.6000 & 0.0038 & 0.0099 & 0.0054 & 1.0000 \\
\hline
\end{tabular}

\subsection{CONCENTRATION OF HG IN GOLD EXTRACTING WASTES}

The concentration of $\mathrm{Hg}$ in gold extracting wastes monitored in disposal sites is shown in Table 2. According to China's standards, the discharging standard value of total $\mathrm{Hg}$ in wastewater is less than $0.05 \mathrm{mg} . \mathrm{L}^{-1}$. From the data obtained, the concentration of $\mathrm{Hg}$ in wastewater from small gold mines was $0.5-1.0 \mathrm{mg} . \mathrm{L}^{-1}$, about 10-20 times of permission value, and the wastewater was discharged to environment without any treatment. The total content of $\mathrm{Hg}$ in solid tailings was terribly high, up to $100-300 \mathrm{mg} \cdot \mathrm{kg}^{-1}$. The tailings were heaped beside the villages, near the river. Apparently, the $\mathrm{Hg}$ in the tailings went to the soil, air, and water eventually.

TABLE 2

Concentration of $\mathrm{Hg}$ in gold extracting wastes

\begin{tabular}{lllll}
\hline $\begin{array}{l}\text { Sample } \\
\text { site }\end{array}$ & $\begin{array}{l}\text { Tailing water } \\
\left(\mathrm{mg} . \mathrm{L}^{-1}\right)\end{array}$ & $\begin{array}{l}\text { Air above Tailings } \\
\left(\mathrm{mg} \cdot \mathrm{m}^{-3}\right)\end{array}$ & $\begin{array}{l}\text { Solid tailings } \\
\left(\mathrm{mg} \cdot \mathrm{kg}^{-1}\right)\end{array}$ & $\begin{array}{l}\text { Waste water } \\
\left(\mathrm{mg} . \mathrm{L}^{-1}\right)\end{array}$ \\
\hline Wang's House & 0.0035 & 0.0112 & 160.75 & 0.6442 \\
Su'House & 0.0021 & 0.0107 & 107.66 & 0.5104 \\
Zhang'House & 0.0065 & 0.0228 & 302.28 & 1.0355 \\
Li'House & 0.0039 & 0.0153 & 184.81 & 0.6697 \\
\hline Average & 0.0040 & 0.0150 & 188.88 & 0.7150 \\
\hline
\end{tabular}

\subsection{CONCENTRATION OF Hg IN THE SURROUNDING ENVIRONMENT}

The concentration of $\mathrm{Hg}$ in the surrounding environment is shown in Table 3 . The water at discharged river mouth was highly polluted, and the concentration of $\mathrm{Hg}$ exceeded its 
background value by 10 to 3000 fold. The $\mathrm{Hg}$ content of soil near the workshop was found to be $1100 \mathrm{mg} \cdot \mathrm{kg}^{-1}$, larger by 1000 fold than the background value (Shuijing Wang, 1995).

TABLE 3

Concentration of $\mathrm{Hg}$ in surroundings

\begin{tabular}{lllll}
\hline Sample & $\begin{array}{l}\text { Drainage } \\
\left(\mathrm{mg} . \mathrm{L}^{-1}\right)\end{array}$ & $\begin{array}{l}\text { Well water } \\
\left(\mathrm{mg.L}^{-1}\right)\end{array}$ & $\begin{array}{l}\text { Discharged mouth } \\
\left(\mathrm{mg.L}^{-1}\right)\end{array}$ & $\begin{array}{l}\text { Background } \\
\text { water }\left(\mathrm{mg} . \mathrm{L}^{-1}\right)\end{array}$ \\
\hline 1 & 0.01164 & 0.0012 & 0.2905 & $<0.0001$ \\
2 & 0.01051 & 0.0010 & 0.3014 & \\
3 & 0.01087 & 0.0010 & 0.3008 & \\
\hline Average & 0.01101 & 0.0011 & 0.2976 & \\
\hline
\end{tabular}

\subsection{ROUGH ESTIMATION OF Hg IN SMALL SCALE GOLD MINES IN 1992-95}

There are 200 sets of extraction and roll mill in Dexing County during 1992-95. Primary ore treated for one set amounted to 4 tons per day, and $1 \mathrm{~kg} \mathrm{Hg}$ for each ton of ore was needed, thus:

$4 \times 2=8 \mathrm{~kg} \mathrm{Hg}$.day ${ }^{-1}$

$200 \times 8=1600 \mathrm{~kg} \mathrm{Hg}$ day $^{-1}$

About $10-20 \%$ of total $\mathrm{Hg}$ was lost. Thus, in Dexing County during operation, every day about $160-320 \mathrm{~kg}$ of $\mathrm{Hg}$ went into the environment. Of the lost $\mathrm{Hg}$, it was estimated that $2 \%$ transformed into $\mathrm{Hg}$ vapor, $80 \%$ was discharged to dumps, and the remainder into soil and waste water.

\subsection{PRELIMINARY EPIDEMIOLOGICAL STUDY}

The concentration of $\mathrm{Hg}$ in urine samples is shown in Table 4. The normal value of concentration of $\mathrm{Hg}$ in human urine is less than $20 \mathrm{ug} . \mathrm{L}^{-1}$ (Weiming Gan, 1995). Most of the tested values were higher than normal value, the highest concentration of $\mathrm{Hg}$ in urine was 50 fold higher. The youngest boy was only two years old.

\section{TABLE 4}

$\mathrm{Hg}$ in urine of 185 villagers*

\begin{tabular}{|c|c|c|c|c|c|}
\hline $\begin{array}{l}\text { Kinds of } \\
\text { persons }\end{array}$ & $\begin{array}{l}\text { Total } \\
\text { number }\end{array}$ & $\begin{array}{l}\text { Number of persons } \\
\text { whose urine } \mathrm{Hg} \\
\text { larger than } 20 \mathrm{ug} . \mathrm{L}^{-1}\end{array}$ & $\begin{array}{l}\text { Range of } \\
\text { urine } \mathrm{Hg} \\
\left(\text { ug. } \mathrm{L}^{-1} \text { ) }\right.\end{array}$ & $\begin{array}{l}\text { Average } \\
\text { urine } \mathrm{Hg} \\
\left(\text { ug. } \mathrm{L}^{-1}\right)\end{array}$ & $\begin{array}{l}\text { Percentage } \\
\text { of abnormal } \\
\text { urine } \mathrm{Hg}\end{array}$ \\
\hline Adult men & 131 & 125 & 3.6 to 289.9 & 66.49 & $95 \%$ \\
\hline Adult women & 21 & 17 & 4.0 to 417.9 & 64.09 & $81 \%$ \\
\hline $\begin{array}{l}\text { Girls under } 16 \\
\text { years old }\end{array}$ & 19 & 14 & 4.7 to 194.5 & 38.13 & $71 \%$ \\
\hline $\begin{array}{l}\text { Boys under } 16 \\
\text { years old }\end{array}$ & 14 & 12 & 8.3 to 539.6 & 86.96 & $86 \%$ \\
\hline Total & 185 & 168 & 3.6 to 539.6 & 65.73 & $91 \%$ \\
\hline
\end{tabular}

* Abnormal is greater than $20 \mathrm{ug} . \mathrm{L}^{-1}$ 


\section{Conclusions}

The preliminary assessment of $\mathrm{Hg}$ in small scale gold mining at Dexing has indicated the serious status of $\mathrm{Hg}$ pollution in China. It affected human health to a great extent. Further study is urgently needed.

Since September 1996, most of the small scale gold mining activities were strictly prohibited by China's national environmental legislation. Recent investigation in late 1996 indicated all those small mines in Dexing County were shut off. There will be changes concerning $\mathrm{Hg}$ pollution status in China. A new study on the assessment of $\mathrm{Hg}$ pollution in small gold mining areas is to begin in 1997-1998

\section{References}

NEPA. 1989. Analytical methods for monitoring water \& waste water, edited by National Environmental Agency (NEPA), 3rd edition, 167-175.

NEPA. 1990. Analytical methods for monitoring air \& waste gases, edited by National Environmental Agency (NEPA), 143-146.

Shuijing Wang. 1995. Environment \& Exploitation 3, 125-135.

Weiming Gan. 1995. Environment \& Exploitation 3, 46-54. 